\title{
FROM THE HISTORY OF AGRARIAN REFORMS IN UZBEKISTAN
}

\author{
Akhmedova Umidaxon Maripjanovna \\ Teacher at the department "Humanitarian subjects" of Andizhan branch of Tashkent State \\ Agrarian University, Republic of Uzbekistan
}

Article DOI: https://doi.org/10.36713/epra3872

\begin{abstract}
In this article has been analyzed history of irrigation system and constructions and their structures in Uzbekistan and its regions by the helping primary sources and scientific literatures as well.
\end{abstract}

KEY WORDS: irrigation, reclamation, pumping station, Uzbekistan, agriculture, reform, water management.

\section{INTRODUCTION}

As a result of agrarian reforms in the country, radical structural changes are taking place in agriculture and water management. Irrigation of new lands is especially important for the development of agriculture. Irrigation is necessary for everything and it will change, prosper and give hope for the future. As early as the Eneolithic period of the 4th millennium $\mathrm{BC}$, irrigated agriculture emerged in the south of Central Asia, rivers and canals were opened, various crops (barley, wheat, rye) were planted, and fruit growing was developed. During the Bronze Age, agriculture based on artificial irrigation formed the basis of the Central Asian economy. Highyielding forms of irrigated agriculture have led to decisive changes in society. In particular, as a result of the development of agriculture, additional products and the appearance of private property appeared.

It is known from history that agriculture based on artificial irrigation was formed and developed in the south of Uzbekistan during the Bronze Age, and in the Tashkent oasis and the Fergana Valley during the Early Iron Age. Archaeologists have discovered that the method of irrigation began to be used about ten thousand years ago. In those days, floodwaters were used to improve the water regime in the soil. It is known that the Nile, Tigris, Amudarya, Syrdarya, Zarafshan rivers were irrigated and cultivated several thousand years ago. Remains of ancient irrigation structures are very common in places where the signs of irrigation of very old times have survived to this day.

\section{METHODS}

Irrigation methods have been used in our country since ancient times in Khorezm, Karakalpakstan, Samarkand, Merv oases, Fergana valley. Remains of ancient irrigation facilities can be found here at every step. According to Herodotus, in ancient times, more than 360 artificial irrigation canals and waterworks were built along the Oks (Amudarya) River, water was pumped to the desert and desert lands, and arable lands were expanded [1, p.5]. By the last quarter of the twentieth century, it became clear that Uzbekistan and neighboring republics, which have ancient traditions and rich experience in agriculture, have serious problems in the agricultural sector. The former Soviet Union's reluctance to take into account local conditions, centuries-old practices, misuse of land and water, and the cultivation of cotton and other water-intensive industrial crops in the agricultural culture has caused serious economic and environmental problems in Uzbekistan. Only after the restoration of national statehood did it provide an opportunity to address these problems, initiate reforms in agriculture, develop a new concept of land and water, and put it into practice immediately. For the Republic, where two-thirds of the population lives in rural areas and is mainly engaged in agriculture, the problem of a new approach to land and water was at the heart of the reforms. In the early years of independence, one of 


\section{SJIF Impact Factor: 7.001| ISI I.F.Value:1.241| Journal DOI: 10.36713/epra2016

the main priorities was to create the necessary conditions for more sustainable development of agricultural production, land reclamation, increasing their productivity and, on this basis, increasing crop yields, as well as improving the organization and financing of irrigation and land reclamation. Today, the Republic of Uzbekistan has adopted a government program for the efficient use of water resources. Various decisions and laws are being adopted in the country to develop this sector.

\section{RESULTS AND DISCUSSIONS}

Improving the reclamation of irrigated lands, development of land reclamation and irrigation facilities, intensive land reclamation in the priorities for modernization and accelerated development of agriculture, identified in the "Strategy of actions on five priority areas of development of the Republic of Uzbekistan in 2017-2021" approved by the President of the Republic of Uzbekistan on February 7, 2017 water and resource-saving, introduction of modern agro-technologies, use of high-efficiency techniques [2]. Adoption of the Decree of the President of the Republic of Uzbekistan dated October 29, 2007 PD3932 "On measures to radically improve the system of land reclamation" was also significant. Resolution of the President of the Republic of Uzbekistan dated April 19, 2013 "On measures to improve the reclamation of irrigated lands and further improve the rational use of water resources", the Cabinet of Ministers of June 21, 2013 "On the introduction of drip irrigation and other water-saving irrigation technologies Resolution of the Government of the Republic of Uzbekistan" dated August 29, 2015 “On measures to effectively organize the financing and socio-economic development of the Aral Sea region for 2015-2018, a comprehensive program of measures to mitigate the consequences of the Aral Sea disaster" and others [3].

Rational use of water resources is one of the global problems today. In the context of growing water shortages due to global climate change, it is important to ensure the efficient use of available water resources and the widespread introduction of cost-effective irrigation technologies to ensure guaranteed yields of agricultural crops and food security of the country's population.

Foreign investments have been attracted to carry out work in this area in accordance with international standards. In particular, in accordance with the Resolution of the President of the Republic of Uzbekistan dated September 10, 2008 No PR-957 and the Ministry of Agriculture and Water Resources dated 26.09.2008 No 165 'On measures to implement the project" Reconstruction of pumping station "Ulugnor" in Andizhan region "The pump station was reconstructed at the expense of foreign investment with the help of a loan from the
Eximbank of the People's Republic of China. The total cost of the project amounted to $11,188,469.0$ thousand soums. It should be noted that according to the agreement between the Ministry of Agriculture and Water Resources of Uzbekistan and China National Electric Equipment Corporation of the People's Republic of China, equipment worth $9,353,048.0$ thousand soums was imported from China and training of chefs, fitters and specialists. work has been done. Construction and installation works amounted to 1,422,290.0 thousand soums and other expenses amounted to 413,131.0 thousand soums". In order to ensure the sustainable development of agricultural production on irrigated lands of Andizhan region, the Joint Directorate of Construction Enterprises No. 2 is responsible for the reconstruction of the pump station "Ulugnor". Pakhtaobod MMC LLC, which was recognized as the general contractor according to the results of the tender to determine the contractor for the contract work at the facility, carried out construction and installation work. Construction and installation work began in June 2009 and was completed in December 2010. Water supply will be improved on 4,088 hectares of land in Andizhan region. Spiritually and technically obsolete, energy-intensive pumps were abandoned. They were replaced by high-energy, lowenergy pumps made in China.

The Eximbank of the People's Republic of China provided a loan for the reconstruction of the Gulbahor-1 pumping station in Jalal-Abad district of Andijan region, the total cost of the project amounted to $11,797,053.0$ thousand soums. In order to ensure the implementation of the Resolution of the President of the Republic of Uzbekistan No. PD-1052 of February 2, 2009 and the Resolution of the Ministry of Agriculture and Water Resources of 06.02.2009 -8 24-8, the Ministry of Agriculture and Water Resources of the Republic of Uzbekistan Equipment in the amount of 9,205,038.0 thousand soums was delivered by Construction and installation works amounted to 2,067,695.0 thousand soums and other expenses amounted to 524,320.0 thousand soums.

The customer of the object is the Joint Directorate of Construction Enterprises No. 2, which won the tender for construction and installation work by "Gidromaxsusmontaj" LLC. Construction and installation work began in June 2009 and was completed in December 2010. Water supply will be improved on 3,668 hectares of land in Andizhan region. Extensive work has also been carried out in the framework of the project for the reconstruction of the pumping station "Raish - Khakent - 1 - 1k" in Andizhan district. The loan of the Eximbank of the People's Republic of China was also involved in the work on this project, which was carried out in accordance with the Decree of the President of the Republic of Uzbekistan dated September 12, 2008 


\section{SJIF Impact Factor: 7.001| ISI I.F.Value:1.241| Journal DOI: 10.36713/epra2016

No. PP-958 and the Ministry of Agriculture and Water Resources dated September 26, 2008 No. 164. The total cost of the project is $4,881,412.0$ thousand soums. The Ministry of Agriculture and Water Resources of Uzbekistan and China National Electric Equipment Corporation of the People's Republic of China imported equipment worth 3,775,570.0 thousand soums. Also, chef-assembly, chef-naladka and training of specialists were carried out. Construction and installation works amounted to $890,770.0$ thousand soums and other expenses amounted to $215,072.0$ thousand soums. The commissioning of this facility was carried out by the Joint Directorate of Construction Enterprises No. 2, and the construction and installation work was carried out by Andizhanmaxsussuvdrenaj LLC. Construction and installation work began in June 2009 and was completed in December 2010. Water supply will be improved on 571 hectares of land in Andijan region.

In recent years, several pumping stations have been reconstructed. In particular, the Shirmonbulak pumping station in Bulakbashi district has been reconstructed in accordance with the Decree of the President of the Republic of Uzbekistan dated April 19, 2013 No PD-1958. The pumping station was reconstructed at the expense of the Capital Construction Fund of the Ministry of Agriculture and Water Resources. The total cost of the project is $2,600,040,274$ thousand soums. The customer of the object is the Joint Directorate of Construction Enterprises No. 2, which won the tender for construction and installation work by "Gidromaxsusmontaj" LLC. Construction and installation work began in February 2013 and was completed in August 2014. Improves water supply of 845 hectares of irrigated lands in B.Rajapov massif of Bulakbashi district.

Pumping station "Blue Dome" of Andizhan district "Program for 2013-2017" approved in accordance with the statement of the Cabinet of Ministers of the Republic of Uzbekistan dated June 4, 2013 No 01-02-70-48 and May 1, 2013 No 01-03 / 1250 carried out on. The pumping station was reconstructed at the expense of the Capital Construction Fund of the Ministry of Agriculture and Water Resources. The construction work was carried out by Gidrospetsmontaj LLC. The total cost of the project is 2,926,160,000 soums. Construction and installation work began in April 2015 and was completed in June 2016. Improves water supply to 401 hectares of irrigated land.

The pump station "Raish - Khakent - 2" in Asaka district was built in accordance with the Decree of the President of the Republic of Uzbekistan dated April 22, 2014 No PP - 2166 and the order of the Ministry of Agriculture and Water
Resources dated April 22, 2014 No 97. The pumping station was reconstructed at the expense of foreign investment. China IPPR International Engineering Corporation Co.Ltd of the People's Republic of China provided equipment worth 11,666,411,911,000 soums and carried out assembly work, training of chefs and specialists. Construction and installation works amounted to 6,202,258,207 thousand soums and other costs amounted to 780,871,745 thousand soums, the total cost of the project was $18,649,541,863$ thousand soums. The construction work was carried out by Andijanmaxsussuvdrenaj LLC. Construction and installation work began in September 2015 and was completed in October 2016. Prior to the reconstruction, 877 hectares of arable land were irrigated with the water extracted by this pump station. After the reconstruction of the pumping station, the area of eein connected to the pumping station was 3260 hectares.

Asaka adir pumping station of Markhamat district was built in accordance with the Decree of the President of the Republic of Uzbekistan dated April 22, 2014 No. PD-2167 and the order of the Ministry of Agriculture and Water Resources dated April 22, 2014 No. 97. The pumping station was reconstructed at the expense of foreign investment. Equipment worth 11,660,038,359,000 soums was delivered by China IPPR International Engineering Corporation Co.Ltd of the People's Republic of China, and chef-assembler, chef-fitter and specialist training were carried out. Construction and installation works amounted to 5,052,862,269 thousand soums, other costs - 596,330.0 thousand soums and the purchase of equipment - 525,840.0 thousand soums, the total cost of the project is $17,835,070,628$ thousand soums. The construction work was carried out by Jalakududdavsuvmaxsuspudrat LLC. Construction and installation work began in September 2015 and was completed in March 2016. Prior to the reconstruction, 2,769 hectares of cropland were irrigated with water extracted using this pumping station.After the reconstruction of the pumping station, the crop area connected to the pumping station was 3,659 hectares. It should be noted that in addition to the reconstructed pumping stations, several new ones have been launched in recent years.

Pumping station "Qurama" of Izbaskan district was implemented under the project "Construction of pumping station" Qurama "to improve the water supply of farms in Izbaskan district", approved by the Protocol of the Scientific and Technical Council under the Ministry of Agriculture and Water Resources of the Republic of Uzbekistan dated August 31, 2016 No 25 . The pump station was newly built at the expense of the Capital Construction Fund of the Ministry of Agriculture and Water Resources. The construction work was carried out by 


\section{EPRA International Journal of Research and Development (IJRD) \\ Volume: 5 | Issue: 6 | June 2020 \\ - Peer Reviewed Journal}

SUE "Jalakudukdavsuvmaxsuspudrat". The total cost of the project is $2,173,748,815,000$ soums. Construction and installation work began in August 2016 and was completed in December 2016. Attached area is 288 hectares.

According to the statement of the Cabinet of Ministers of the Republic of Uzbekistan No. 06-06 / 1495 dated June 13, 2012, the pumping station "Boghi-Bobur" of Andizhan district was implemented under the project "Construction of the pumping station" Boghi-Bobur in Andizhan district of Andizhan region. The pump station was newly built at the expense of the Capital Construction Fund of the Ministry of Agriculture and Water Resources. The construction work was carried out by SUE "Jalakudukdavsuvmaxsuspudrat". The total cost of the project is 219,899,668 thousand soums. Construction and installation work began in October 2012 and was completed in December 2013. The attached area is 86 hectares.

Pump station "JFK" of Khojaabad district was implemented in accordance with the Decree of the President of the Republic of Uzbekistan dated December 23, 2016 No PD-2697 on the project "Construction of a pumping station in the South Ferghana canal in Khojaabad district of Andizhan region". The pump station was newly built at the expense of the Capital Construction Fund of the Ministry of Agriculture and Water Resources. The construction work was carried out by Gidrospetsmontaj LLC. The total cost of the project is $27,474,862,172,000$ soums. Construction and installation work began in June 2016 and was completed in December 2018. The attached area is 2800 hectares.

\section{CONCLUSION}

The widespread introduction of water-saving technologies in our country, the use of facilities created by the state for this purpose, contributes to the development of agricultural production and further increase the welfare of our people. As a result of the expansion of irrigation networks, the timely supply of water to farmers is yielding positive results. The unprecedented expansion of irrigation networks, combined with a high degree of mechanization of agricultural work and the use of advanced agricultural machinery, serves to increase the productivity of farmers.

\section{REFERENCES}

1. R.Shamsutdinov, H.Muminov History of Uzbekistan. -Andizhan, 2011.

2. Scientific-methodical pamphlet on the study of the State Program for the implementation of the Action Strategy on the five priority areas of development of the Republic of
Uzbekistan for 2017-2021 in the "Year of dialogue with the people and the interests of man". Tashkent, 2017.

3. 3.M.Turdiboeva Rational use of land and water resources: problems, history and results // Spiritual-educational and political maturity - a guarantee of social development. - T .: 2016. 165 p.

4. From the 2010 report of the NarynKaradarya Irrigation Systems Basin Department.

5. From the 2014 report of the NarynKaradarya Irrigation Systems Basin Department.

6. From the 2016 report of the NarynKaradarya Irrigation Systems Basin Department. 